\title{
Redes de subcontratação e trabalho a domicílio na indústria de confecção: um estudo na região de Campinas*
}

\author{
Angela Maria Carneiro Araújo** \\ Elaine Regina Aguiar Amorim ***
}

\begin{abstract}
Resumo
Este artigo tem como propósito discutir as redes de subcontratação $e$ os novos "usos" do trabalho a domicílio como elementos centrais do processo de reestruturação do setor de confecção nos anos 90, bem como seus impactos sobre as condições de trabalho e saúde das mulheres trabalhadoras. Para isso, partimos de uma pesquisa realizada na região de Campinas/SP, que contemplou o estudo de empresas de confecção de pequeno e médio porte, como também uma extensa rede de subcontratação, que tem na sua ponta inferior o trabalho a domicilio. A pesquisa mostra que as mulheres constituem a força de trabalho tradicionalmente subcontratada pelas empresas confeccionistas e ocupam as posições inferiores e mais vulneráveis na cadeia produtiva. Mostra também que o trabalho a domicilio aparece revitalizado, como instrumento central de aumento da produtividade a baixos custos e como forma alternativa de enfrentar a concorrência com grandes empresas do ramo.
\end{abstract}

Palauras-chaves: Trabalho Feminino, Indústria de Confecção, Redes de Subcontratação, Trabalho a Domicílio.

\footnotetext{
* Recebido para publicação em novembro de 2001.

*** Professora do Departamento de Ciência Política do Instituto de Filosofia e Ciências Humanas - IFCH/Unicamp.

**** Mestranda em Sociologia no IFCH/Unicamp.
} 
Redes de subcontratação

\author{
Undercontracting Networks and Household Labor \\ in the Clothing Industry: \\ a Study of the Campinas'Region
}

\begin{abstract}
This article discusses the undercontracting networks and the new "usages" of household labor as central elements of the restructuring processes of the clothing sector in the nineties, as well as their impact on the labor and health conditions of the working women. This is done through research in the Campinas region, State of São Paulo on small and medium sized clothing industries, including the wide undercontracting network, whose lowest point is household labor. Data show that women are the hands traditionally undercontracted by the clothing industries and that they work on the lowest and most vulnerable positions in the productive chain. They also show that household labor looks renewed, as a central instrument of productivity increase at low cost and as an alternative way of entering the competition with the larger industries.
\end{abstract}

Key words: Female Labor, Clothing Industry, Undercontracting Networks, Household Labor. 
Angela Carneiro Araújo, Elaine Aguiar Amorim

\section{Introdução}

A aceleração do processo de reestruturação produtiva nos anos 90, em um contexto de crise e globalização da economia, vem sendo acompanhada no Brasil, como em outros países, de uma intensificação do uso de distintas formas de subcontratação bem como do trabalho a domicílio.

A subcontratação constitui-se como um elemento central dos novos modelos produtivos, derivada das práticas de enxugamento e focalização das empresas, e fundamentalmente da busca de maior flexibilidade da produção e das relações de emprego. Sua intensificação e generalização nos mais distintos setores da indústria têm levado a um crescimento explosivo de pequenas e micro empresas, que é visto como parte de um processo mundial de descentralização da produção e crescente informalização. ${ }^{1}$ Estudos internacionais mostram que a subcontratação tem sido crescentemente utilizada como um processo de gerenciamento das mudanças organizacionais, da força de trabalho $e$ das relações industriais. Motivações $e$ problemas comuns têm sido identificados em diferentes setores e países. Se razões econômicas, como redução de custos e a crescente competitividade, foram destacadas como as principais motivações das empresas para a externalização de atividades, considerações de ordem política e filosófica também aparecem freqüentemente como importantes. Assim,

a vontade de aumentar a flexibilidade do mercado de trabalho, de rever as práticas do trabalho e, em particular, de reduzir o poder dos sindicatos, têm sido, todas elas,

\footnotetext{
1 YPEIJ, Annelou. Transfering risks, microproduction and subcontracting in the footwar and garment industries of Lima, Peru. Latin American Perspectives, vol. 25, n² 2, march 1998 .
} 
Redes de subcontratação

incentivos poderosos à adoção da subcontratação tanto no setor privado quanto no público. ${ }^{2}$

No Brasil, cadeias de subcontratação, nas quais são encontradas distintas formas de relações entre empresas ou entre empresas e trabalhadores, generalizaram-se, ao longo da última década, em diferentes setores da economia, como parte da estratégia das empresas de assegurar condições de competitividade seja no mercado nacional ou no mercado global. Assim é possivel encontrar hoje, no país, extensas redes de subcontratação que têm na sua ponta superior grandes empresas multinacionais atuando no mercado global; empresas atuando como subcontratadas numa cadeia global, que tem como principal cliente uma grande companhia com matriz no exterior ou pequenas redes de subcontratação vinculadas a empresas de médio e pequeno porte atuando basicamente no mercado nacional. Em muitas destas redes é possível encontrar em sua ponta inferior o uso do trabalho a domicílio.

A indústria de confecção, por ser um ramo industrial baseado no uso intensivo de mão-de-obra, cuja produção se desenvolveu com poucas inovações técnicas, limitadas à máquina de costura industrial e ao trabalho manual, caracterizou-se desde seus primórdios pelo uso contínuo de diversas formas de trabalho subcontratado, principalmente do trabalho a domicílio.

$\mathrm{O}$ intenso processo de reestruturação pelo qual vem passando este setor nas duas últimas décadas tem levado, no novo contexto da competição globalizada, ao crescimento de algumas grandes empresas e ao declínio de outras, à compra de competidores por multinacionais, $e$ ao desenvolvimento de franchises internacionais. Ao lado disto, a explosiva expansão da produção em pequena escala, das micro empresas e do trabalho a

2 YounG, Suzanne. Outsoursing: lessons from the Literature. Labour \& Industry, vol. $10, n^{\circ} 3$, abril de 2000 . 
domicílio, constituem conseqüências visíveis da intensificação do movimento de subcontratação.

Com isso, este artigo tem como propósito discutir o processo de subcontratação como parte da reestruturação no setor de confecção a partir da análise das cadeias de subcontratação e dos novos "usos" do trabalho a domicílio e seus impactos sobre as condições de trabalho e saúde de homens e mulheres trabalhadores. Para isso, partimos de um estudo de caso realizado entre 1998 e 2000 na região de Campinas/SP ${ }^{3}$, envolvendo empresas de confecção, cadeias produtivas compostas por empresas subcontratadas de diferentes portes e trabalhadoras domiciliares. Ao longo da pesquisa foram realizadas entrevistas com proprietários, gerentes e operários/as de algumas empresas, assim como com os presidentes do Sindicato Patronal e do Sindicato dos Trabalhadores, além das entrevistas com as empresas prestadoras de serviços e com costureiras que trabalham no próprio domicílio.

\section{As formas de subcontratação}

Com o objetivo de distinguir o fenômeno mais recente da externalização de serviços ou produção, associado aos processos de reestruturação, das formas tradicionais de subcontratação, Young distingue outsourcing de subcontracting. Outsourcing (que neste texto traduziremos por terceirização) é definida como o ato de uma empresa transferir a provisão de serviços ou de atividades produtivas, antes desenvolvidas por ela nas suas próprias instalações, para uma terceira parte que assume a responsabilidade da execução destas atividades para a empresa

\footnotetext{
3 Aqui estamos considerando por "região de Campinas" o espaço geográfico composto por cidades localizadas próximas ao município de Campinas pesquisadas por nós - Campinas, Cosmópolis, Bragança Paulista, Hortolândia, Sumaré e Limeira.
} 
Redes de subcontratação

contratante sob determinadas condições contratuais. ${ }^{4}$ Esta definição inclui a possibilidade de que a execução das atividades terceirizadas seja realizada no interior da empresa contratante, mas supõe que a terceira parte (seja ela uma empresa ou trabalhadores autônomos) esteja fora das relações e condições de emprego que governam os empregados da contratante.

As formas tradicionais de subcontratação são vistas por esta autora como as que se encontram, por exemplo, na provisão de materiais da indústria da construção civil e seriam equivalentes à contratação de fornecedores de produtos ou serviços completos. No setor de confecção, a terceirização, como definida por Young, corresponde não apenas a uma prática recente, mas à forma tradicional de subcontratação presente desde o início do desenvolvimento desta indústria através da prática do putting out.

A compreensão das diferentes modalidades de terceirização, de relações entre contratantes e subcontratados observadas neste setor, como parte do processo recente de reestruturação, exige o estabelecimento de duas distinções. Ypeij ${ }^{5}$ distingue a subcontratação parcial e a completa $e$ suas formas equivalentes $e$ assimétricas.

Na subcontratação parcial, a empresa contratante transfere parte da produção a uma terceira parte, mas fornece as matérias primas e/ou produtos semi-manufaturados necessários $e$, em alguns casos, inclusive o maquinário. A subcontratada é responsável por uma parte do processo de fabricação $e$, em geral, quando ela termina sua tarefa o produto recebe ainda um processamento final na firma contratante. No caso da subcontratação completa, a empresa contratante transfere à subcontratada a fabricação completa do produto, provendo a ela apenas suas etiquetas e material de embalagem. Estas duas

\footnotetext{
${ }^{4}$ Ver também ReILLY, P. and TAMKIN, P. Outsoursing: a flexible option for the future? IES Report 320, The Institute for Employment Studies, Brighton, UK, 1996.

5 YPEIJ, A. Transfering risks, microproduction... Op. cit.
} 
modalidades de subcontratação não são mutuamente excludentes, mas constituem pólos de um continuum.

A subcontratação assimétrica geralmente se estabelece entre empresas de porte diferente, ou seja, entre grandes e pequenas empresas e envolve relações desiguais de poder e subordinação. $\mathrm{Na}$ maioria das vezes, os vínculos entre estas empresas assumem a estrutura de uma pirâmide, com poucas grandes empresas no topo e uma graduação crescente de médias e pequenas empresas nos níveis inferiores em direção à base. ${ }^{6} \mathrm{~A}$ forma de subcontratação equivalente envolve empresas que tem tamanho semelhante. Esta é a forma predominante no setor de confecção da região de Campinas e envolve uma gradação de pequenas empresas e micro-produtores, que são, na maioria das vezes, costureiras trabalhando a domicílio. Nestas duas formas de subcontratação, no entanto, é possível encontrar relações entre o setor formal e informal bem como relações de subordinação em variados graus entre subcontratadas e contratantes.

De acordo com Ypeij ${ }^{7}$, distintos graus de subordinação estão diretamente relacionados com a subcontratação parcial e com a subcontratação completa. Esta última permite ao/à produtor/a deter maior autonomia em relação à empresa contratante, na medida em que ele/a toma as decisões centrais relativas à compra de matéria-prima, ao uso da subcontratação, e à forma de organização da produção. Além disto, ele/a é o/a proprietário/a do produto até o momento da sua entrega ao contratante. No caso da subcontratação parcial, como os/as produtores/as se envolvem

\footnotetext{
${ }^{6}$ Ypeij, citando Beneria e Roldan, menciona também a estrutura em formato de diamante em que uma grande empresa subcontrata várias firmas de médio ou pequeno porte para a produção de um mesmo produto. E ocasionalmente acontece que uma empresa pequena especializada na elaboração de uma parte deste produto recebe pedidos das várias subcontratadas da grande contratante. Apud BENERIA, Lourdes e RoLDAn, Martha. The Crossroads of Class and Gender, Industrial Homework, Subcontracting, and Household Dynamics in México City. Chicago and Lodon, University of Chicago Press, 1987.

7 ID., IB.
} 
Redes de subcontratação

em apenas uma parte da produção, e não têm contato com fornecedores e nem com os pontos de venda do produto final, seu controle sobre o processo produtivo é muito mais limitado e é maior sua subordinação ao contratante. A perda de independência do/a pequeno/a ou micro-produtor/a é ainda maior quando o/a contratante fornece o maquinário necessário à fabricação. Esta relação de subordinação se transfere para as pontas inferiores da cadeia, mesmo no caso da subcontratação equivalente, quando pequenas ou microempresas subcontratadas, transferem por sua vez parte da produção para outras/os micro-produtoras/es ou para trabalhadoras/es a domicílio, o que constitui uma prática comumente empregada nas indústrias de calçado e de confecção para a redução de custos e aumento da produtividade.

No Brasil, estudos recentes têm chamado atenção para existência de duas modalidades de terceirização: a primeira, considerada mais virtuosa, consiste num instrumento de melhoria da qualidade, da produtividade e da competitividade, na medida em que inovações tecnológicas e organizacionais são transferidas para as empresas subcontratadas e se difundem ao longo da cadeia. Na segunda modalidade, a terceirização ocorre com o objetivo central de redução de custos e, nesta medida, o que se transfere às subcontratadas são os gastos e os riscos da produção e o custo da mão-de-obra. Neste caso, a exigência de preços baixos dá-se, muitas vezes, em detrimento da qualidade. E é esta segunda modalidade que, segundo vários estudos, tem se generalizado no país com conseqüências danosas para os trabalhadores nelas envolvidos. ${ }^{8}$

8 DruCK, M. G. Terceirização: (Des)Fodizando a Fábrica. Tese de Doutorado, Campinas, Instituto de Filosofia e Ciências Humanas/UNICAMP, 1995; RUAS, Roberto. Notas Acerca das Relações entre Trabalho a Domicílio, Redes de Subcontratação e as Condições de Competição. In: ABREU, A. R. de P. e SORJ, B. (orgs.) O Trabalho Invisível: Estudos Sobre o Trabalho a Domicílio no Brasil. Rio de Janeiro, Rio Fundo, 1993; GITAHY, Leda. Inovação tecnológica, Subcontratação e Mercado de Trabalho. São Paulo em Perspectiva, no 8(1), jan/mar de 1994, pp.144-153. 
Empregada na maioria dos casos como expediente de redução de custos, a terceirização tem imposto aos trabalhadores relações de emprego instáveis, redução de salários e benefícios e condições de trabalho degradadas, que tem como conseqüência o aumento dos acidentes de trabalho e das doenças profissionais. Além disto, ela tem levado ao desalojamento de uma parcela dos/as trabalhadores/as para a economia informal, submetendoos/as a condições precárias de trabalho e excluindo-os/as dos benefícios assegurados por lei e da representação sindical. ${ }^{9}$

Pesquisas realizadas nas cadeias produtivas e nas redes de subcontratação têm permitido salientar a natureza complexa $e$ contraditória dos processos de reestruturação. ${ }^{10}$ É igualmente uma característica central destes processos a reprodução de condições desiguais de trabalho entre mulheres e homens. ${ }^{11}$ Como observa Abramo $^{12}$, o processo de precarização presente nas cadeias de subcontratação, que se constituem a partir de uma assimetria de poder entre as empresas e de uma lógica de redução de custos, "está fortemente marcado por uma variável de gênero". As mulheres são encontradas em maior número principalmente nas empresas subcontratadas das pontas inferiores da cadeia

9 BRESCIANI, Luís Paulo. Reestruturação industrial e negociação coletiva: o sindicalismo brasileiro vai à luta? In: MARTINS, Heloísa de S.; RAMALHO, J. (orgs.) Ricardo. Terceirização: Diversidade e negociação no mundo do trabalho. São Paulo, Hucitec, 1994; DRUCK, M. G. Globalização, Reestruturação Produtiva e Movimento Sindical. Caderno CRH, Salvador, ns 24/25, 1996.

${ }^{10}$ LeITE, Márcia de P. A cadeia automotiva: da linha de montagem robotizada ao trabalho escravo. Relatório Técnico de Pesquisa, mimeo, 1996; ABRAMO, Laís. Um olhar de gênero. Visibilizando precarizações ao longo das cadeias produtivas. In: ABRAmo, L. e ABREU, Alice R. P. (orgs.) Gênero e Trabalho na Sociologia Latino-Americana. São Paulo/Rio de Janeiro, ALAST, 1998.

${ }^{11}$ LOMBARDI, Maria. R. Reestruturação produtiva e trabalho: Percepções dos trabalhadores. Educação\&Sociedade, n 61, 1997; HIRATA, Helena. Reestruturação Produtiva e Relações de Gênero. Revista Latinoamericana de Estudos do Trabalho, ano 4, n 7, 1998.

${ }^{12}$ ABramo, L. e ABreu, A. R. P. (orgs.) Gênero e Trabalho... Op. cit., p.40. 
Redes de subcontratação

produtiva, nas quais predominam o trabalho taylorizado, as piores condições de trabalho e vínculos empregatícios precários.

Em grandes indústrias, em geral, os estágios da produção terceirizados para pequenas, micro empresas ou para o trabalho a domicílio são precisamente aqueles nos quais predominam uma maioria de mulheres. A externalização destas atividades é facilitada pelo fato de constituírem partes do processo produtivo intensivos em mão-de-obra, nos quais o maquinário é mais simples e facilmente transportável e a subcontratação pode se realizar sem problemas técnicos. Além disto, as habilidades necessárias à execução das tarefas externalizadas são, em geral, adquiridas pelas mulheres através do processo de socialização $e$ de formação de gênero no espaço doméstico. Mas o grande estímulo à subcontratação das tarefas nas quais predomina a mãode-obra feminina vem também do fato de que as empresas podem se beneficiar dos salários mais baixos que são pagos às trabalhadoras nas pequenas e micro empresas e no trabalho a domicílio. $^{13}$

Estudos do mercado de trabalho confirmam o bias de gênero presente nos processos de reestruturação ao mostrar que as mulheres têm sido deslocadas "dos setores e ocupações nos quais sempre marcaram presença", assim como "de atividades industriais de grande porte, para pequenos e médios estabelecimentos comerciais". ${ }^{14}$ Além disto, sua incorporação crescente ao mercado de trabalho vem se dando principalmente através dos contratos por tempo determinado, dos trabalhos com jornada parcial, das atividades por conta própria e do trabalho a domicílio, que vem sendo utilizado com mais freqüência como forma de redução dos custos do trabalho, ou ainda nos postos

\footnotetext{
${ }^{13}$ YPEIJ, A. Transfering risks, microproduction... Op. cit.

${ }^{14}$ BRusChINI, Cristina. Trabalho das mulheres no Brasil: continuidades e mudanças no período 1985-1995. Textos FCC, no 17, São Paulo, Fundação Carlos Chagas/DPE, 1998, p.71.
} 
Angela Carneiro Araújo, Elaine Aguiar Amorim

sem registro legal das empresas subcontratadas tanto no setor de serviços ${ }^{15}$ quanto na indústria. ${ }^{16}$

Estas modalidades de contratação, que vem se constituindo como os novos (ou renovados, como no caso do trabalho a domicílio) espaços de confinamento da mão-de-obra feminina, contribuem para que a incorporação das mulheres se dê sob condições de trabalho precárias e inseguras, marcadas pelos baixos salários, pela intensificação da carga de trabalho, e pela perda dos direitos legais. Deste modo, para as mulheres trabalhadoras as novas formas de exclusão se sobrepõem aos antigos mecanismos de exclusão de gênero, potencializando-os.

\section{A indústria de confecção no Brasil}

A crise econômica instaurada no país no início da década de 90 e principalmente o processo de abertura comercial iniciada no Governo Collor levou a indústria de confecção a sofrer um dos seus piores períodos de recessão. A entrada de produtos importados, especialmente de tecidos e roupas em grande volume $e$ a preços baixos, provocou a redução da produção ou suspensão das atividades produtivas em muitas empresas e até mesmo a falência de algumas delas. No período de 1993-1995, no Estado de

\footnotetext{
${ }^{15}$ Dados recentes para São Paulo indicam que o setor de serviços e o serviço doméstico, em especial, nos quais se encontram, respectivamente, $48,5 \%$ e $19,1 \%$ das mulheres empregadas em 1997, foram os únicos a apresentar crescimento do emprego entre 1996 e 1997. Estes dados mostram também que decresceu a participação de ambos os sexos no emprego assalariado com registro legal, sendo este decréscimo mais pronunciado entre as mulheres que diminuíram sua participação de 48,3\% em 1996 para 46,3\% em 1997.

${ }^{16}$ Ver ABREU, Alice P. e SORJ, Bila. (orgs.) O Trabalho invisível: estudos sobre trabalhadores a domicílio no Brasil. Rio de Janeiro, Rio Fundo Editora, 1993; Desigualdade de gênero e raça: o informal no Brasil em 1990. Estudos Feministas, $\mathrm{n}^{\circ}$ especial, CIEC/ECO/UFRJ, Rio de Janeiro, outubro de 1994; BRUSCHINI, Cristina e LOMBARDI, Maria Rosa. O trabalho da mulher brasileira nos primeiros anos da década de noventa. Anais do Encontro Nacional de Estudos Populacionais, Belo Horizonte, ABEP, 1996; BRUSCHINI, C. Trabalho das mulheres no Brasil... Op. cit.
} 
Redes de subcontratação

São Paulo o número de falências no setor de vestuário, calçados e artefatos de tecidos aumentou $86,88 \%$ e a contribuição do segmento do vestuário para o aumento do desemprego entre os anos 1993-1996 correspondeu a 40,6\%. Nesse contexto, somente na segunda metade da década (1994-1996), ocorreu um aumento do número de estabelecimentos confeccionistas, principalmente nos estados em que predominava um maior número de confecções (MG, RJ, SP, PR e SC). Entretanto, é importante ressaltar que este crescimento se verificou principalmente nas pequenas e micro empresas e não inclui as empresas de médio porte que decresceram nesse mesmo período em contraste com um ligeiro crescimento verificado entre 1991-1993. ${ }^{17}$

Desprotegidas diante nas novas condições impostas pela mudança na política econômica, e marcadas por um aparato produtivo defasado em relação ao mercado externo, muitas empresas começaram a buscar alternativas que garantissem sua permanência no mercado interno e o resgate da sua capacidade competitiva. Em resposta à crise, inicia-se, então, lentamente e de forma bastante heterogênea, um processo de reestruturação do setor de confecções. Indícios do movimento de modernização do setor são o crescimento do parque de máquinas, instalado no período de 1993 a 1995, e a diminuição da idade média dos equipamentos. ${ }^{18}$

Entretanto, esta é uma indústria intensiva em mão-de-obra, cuja etapa principal do ciclo produtivo, a costura, absorve $80 \%$ do trabalho vivo, que tem alta participação no custo total. A inovação tecnológica, assim, tem se verificado principalmente nas etapas anteriores à costura, através da utilização dos sistemas CAD nas fases de design, modelagem, gradeamento e encaixe, e de

${ }^{17}$ VerSIANI, Angela França e GASPAR, Renata de Magalhães. Diferenças e similaridades entre micro, pequenas e médias empresas do segmento de confecção na região metropolitana de Belo Horizonte. In: NABUCO, M. R. e NETO, A. C. (orgs.) Relaçôes de Trabalho Contemporâneas. Belo Horizonte, PUCMINAS/IRT, 1999, p.238.

18 Id., ib. 
equipamentos de controle numérico na fase do corte. No entanto, as especificidades $e$ inovações na principal matéria-prima (o tecido), as especificidades e fragmentação do mercado bem como o alto custo dos novos equipamentos dificulta a superação da defasagem tecnológica $e$ "faz com que a indústria de confecção ainda se estruture no binômio máquina de costura/costureira". ${ }^{19}$

Característica central deste movimento de reestruturação dos anos 90, a terceirização difunde-se e ganha novos contornos em meio às inovações gerenciais e tecnológicas empregadas. A subcontratação de oficinas de costura $e$ o uso do trabalho a domicílio se intensificam, na medida em que se tornam a principal estratégia utilizada pelas confecções, independente do seu tamanho e posição no mercado, com o objetivo de reduzir custos e aumentar sua capacidade produtiva.

Pesquisas realizadas ao longo dos anos 90 em diferentes estados do país têm mostrado como a reestruturação no setor de confecção vem se processando de forma diferenciada conforme as características regionais e as estratégias empresariais. Elas nos mostram, de um lado, grandes empresas do setor que investiram na modernização tecnológica nas fases de desenho, modelagem $e$ também na montagem, através de equipamentos de base microeletrônica, mas adotaram, apenas de forma parcial, métodos de gestão da qualidade, como o programa " $5 \mathrm{~S}$ ", sem, no entanto, alterar de forma substancial a organização da produção e a forma de gestão da força de trabalho. ${ }^{20}$

Por outro lado, estudos realizados em região do interior cearense, em Minas Gerais e no Rio de Janeiro mostram como a subcontratação, nas suas distintas formas, incluindo o trabalho a domicílio, passou a ser empregada como instrumento central de

\footnotetext{
${ }^{19}$ Id., ib., p.252.

${ }^{20}$ GazzANA, Raquel da Silva. Trabalho feminino na indústria do vestuário. Educação \& Sociedade, n 61, 1997.
} 
Redes de subcontratação

aumento da produtividade. Moreira ${ }^{21}$ analisa o papel de uma grande empresa de capital estrangeiro, na região do Maciço do Baturité (CE), na criação de uma rede de cooperativas de confeccionistas para atuarem como suas subcontratadas. Com o apoio do governo do Estado, a empresa Kao Lin fundou um Centro Tecnológico de Formação de Confeccionistas (responsável pelo treinamento e pelo encaminhamento das trabalhadoras às cooperativas de confecção) e avalizou empréstimos junto ao Banco do Nordeste para financiamento de máquinas $e$ equipamentos adquiridos pelas cooperativas. ${ }^{22}$ A estratégia da empresa, neste caso, foi escolher um green field, caracterizado pela abundância de mão-de-obra barata e desorganizada, para organizar sua produção através da subcontratação de trabalhadoras reunidas nestas cooperativas como autônomas e, portanto, sem manter com elas qualquer contrato formal ou vínculo empregatício.

No caso de Belo Horizonte, Versiani e Gaspar $^{23}$ mostram que o setor de confecção, caracterizado pela predominância de pequenas e micro empresas, tem enfrentado a concorrência na última década principalmente através da compressão das margens de lucro e da redução dos preços de seus produtos. O survey realizado com as empresas do setor mostra que a modernização tecnológica é incipiente e que as inovações gerenciais são pouco difundidos. A maioria das empresas não as adota e demonstra desconhecimento do real significado e implicações dos principais métodos de gestão. Assim, a redução de mão-de-obra $e$ a terceirização aparecem como as principais estratégias adotadas e são vistas, pela maioria das empresas, como indispensáveis para a

${ }^{21}$ MoReIRA, Maria. V. C. A inserção da mão-de-obra feminina na indústria de confecção no Ceará; o caso das Cooperativas de Confecções do Maciço de Baturité. Caderno CRH, ns 26/27, Salvador, 1997.

22 Estes equipamentos foram adquiridos com a empresa Yamacon pertencente ao mesmo grupo de investidores de Taiwan.

${ }^{23}$ Versiani, A. F. e GASPAR, R. M. Diferenças e similaridades... Op. cit. 
melhoria da sua competitividade já que propiciam redução de encargos trabalhistas e ganhos de produtividade. Aqui, como em outros setores industriais, portanto, a via precarizadora da redução de custos é privilegiada.

O trabalho a domicílio de costureiras - tradicionalmente utilizado neste setor, principalmente em momentos de pico de produção, como forma de responder a aumentos sazonais na demanda - foi revitalizado e adquiriu novas proporções como a ponta inferior e mais frágil nas redes de terceirização no contexto da reestruturação dos anos 90 . Pesquisas realizadas no Rio de Janeiro por Abreu e Sorj ${ }^{24}$ mostraram a vulnerabilidade das costureiras trabalhando a domicílio, que, para garantir a continuidade do trabalho e uma remuneração satisfatória, se submetiam a um intenso ritmo de trabalho, pois, do contrário, não podiam manter o nível de produtividade e a pontualidade da entrega exigidos pelas empresas contratantes. Essas trabalhadoras, em grande parte mulheres de meia idade, casadas e com filhos, correspondiam ao perfil preferido pelos empregadores, na medida em que constituíam um grupo qualificado e com experiência, mas com poucas chances de ser empregado formalmente e, por isso, dispostas a aceitar o pagamento por peça e a baixa remuneração imposta por eles.

Muitos desses estudos sobre a reestruturação do setor de confecção têm em comum o fato de chamarem atenção para os impactos negativos deste processo sobre o trabalho feminino. De um lado, principalmente nas grandes e médias empresas, parte importante das trabalhadoras tem enfrentado o desemprego devido aos processos de enxugamento, enquanto para as que permaneceram empregadas as exigências de maior envolvimento e qualidade do trabalho são combinadas com a manutenção de práticas tayloristas na organização do trabalho e com a intensificação do ritmo de trabalho, sem contrapartida em termos de novos benefícios ou melhoria salarial. De outro, os processos

${ }^{24}$ AbreU, A. R. de P. e SoRJ, B. (orgs.) O Trabalho Invisível... Op. cit. 
Redes de subcontratação

de terceirização, através do emprego de formas de trabalho precário e informal (cooperativas de confeccionistas, trabalho a domicílio), têm tirado proveito da disponibilidade de uma força de trabalho crescentemente excluída das oportunidades formais do mercado de trabalho.

\section{A indústria de confecção na região de Campinas}

A indústria de confecção na região de Campinas caracterizase pela presença predominante de empresas de pequeno e médio porte atuando no mercado local ou nacional. A produção em grande parte está voltada para a confecção de vestuário e de peças de cama e mesa, o que possibilita a utilização de um maquinário com baixo conteúdo tecnológico - a máquina de costura industrial - ainda muito dependente do trabalho manual.

As pequenas e médias empresas confeccionistas da região apresentam características comuns com aquelas de outras localidades do país. Dedicando-se na sua maioria à indústria da moda, voltada para um mercado segmentado de acordo com a renda, tendo que atender a uma demanda altamente variável, estas empresas produzem produtos customizados em pequenos lotes. Predomina entre elas uma mentalidade empresarial conservadora, pouco disposta a investir na modernização tecnológica ou organizacional e que privilegia o recurso à informalização e ao trabalho a domićlilio ${ }^{25}$ como forma de ampliação da capacidade instalada.

$\mathrm{O}$ fato do setor de confecção não necessitar de um alto montante de capital para ativar a produção e basear-se no uso intensivo de mão-de-obra aliado às condições de um mercado protegido permitiu o crescimento da produção nos anos $80 \mathrm{sem}$

${ }^{25}$ Versiani e Gaspar observam como a indústria de confecção se caracteriza pela fragmentação devido à quase inexistência de barreiras de entrada, a informalização $e$ o uso do trabalho a domicílio parecem constituir aspectos estruturais. VERSIANI, A. F. e GASPAR, R. M. Diferenças e similaridades... Op. cit., p.250. 
que se verificasse investimentos em novos equipamentos $e$ na ampliação da estrutura produtiva. De acordo com o depoimento do Presidente do Sindicato da Indústria de Confecção de Campinas, no contexto dos anos 80, empresários do setor preferiram investir seus lucros em outros ramos da economia do que na modernização do aparato produtivo ou na melhoria das condições de trabalho de suas empresas.

Assim, o setor de confecção na região, como de resto em todo o país, estava despreparado para enfrentar a crise econômica $e$ as novas condições de concorrência introduzidas nos anos 90 com a mudança da política econômica. A abertura comercial iniciada no Governo Collor estabeleceu, na visão dos empresários e gerentes entrevistados, uma "concorrência desleal" ao permitir a importação em grande escala de produtos baratos e, em alguns casos, com qualidade superior aos produtos nacionais, provocando uma crise generalizada no setor, além de tornar visível o atraso tecnológico e a baixa produtividade de grande parte das empresas.

Os dados relativos à evolução do emprego por gênero $e$ tamanho de empresa neste setor nos anos 90 permitem perceber os impactos desta crise sobre o volume e a composição da força de trabalho bem como as conseqüências do ajuste realizado sobre a estrutura industrial.

A Tabela 1 mostra que um dos efeitos importantes da crise econômica e da abertura comercial sobre o setor de confecção foi uma redução drástica do volume do emprego. A queda no número de postos de trabalho, de 56,8\% entre 1990 e 1998, parece estar diretamente associada aos períodos de crise econômica e de concorrência aberta com produtos importados, que ocorreram no começo da década (1990/92) e a partir de 1994, quando foi implantado o Plano Real e reintroduzida com mais força a política de eliminação de barreiras alfandegárias para importação de peças de vestuário.

A evolução do emprego de acordo com o tamanho das empresas, além de confirmar a predominância na região das 
Redes de subcontratação

micro e pequenas empresas com até 99 funcionários, que representavam cerca de $80 \%$ do emprego em 1998, oferece indícios do tipo de ajuste empreendido e seu impacto sobre a estrutura industrial do setor .

A Tabela I mostra uma tendência de redução gradativa das empresas de porte médio e o fechamento da única grande empresa da região (com mais de 500 funcionários), a partir de 1995. Embora a redução do emprego tenha se dado de forma generalizada, nas médias empresas (empregando de 100 a 499 funcionários) ela ocorreu de forma abrupta correspondendo a uma redução de $69,8 \% .{ }^{26}$ A queda do emprego também é significativa nas empresas que agregavam entre 50 e 99 empregados, já que em 1998 a força de trabalho contratada correspondia a $37,2 \%$ do total registrado em 1990. Nas pequenas empresas com até 49 trabalhadores, no entanto, a redução de postos de trabalho ocorreu em menor proporção, sendo que sua participação no volume do emprego do setor cresceu de $39,13 \%$ em 1990 para 59,8\% em 1998.

Este aumento da fragmentação da produção é um indicador de que nos anos 90 as empresas da região realizaram um ajuste defensivo baseado, fundamentalmente, no enxugamento das empresas e na externalização da produção para pequenas oficinas subcontratadas ou para o trabalho a domicílio, com o objetivo de reduzir custos. Como os dados da Tabela I referem-se apenas ao trabalho formal, eles não captam um possível crescimento do trabalho informal neste setor. Mas o crescimento da participação das empresas com até 49 trabalhadores no conjunto do emprego indica o crescimento das pequenas oficinas e o surgimento de novas como resultado do intenso movimento de terceirização.

${ }^{26}$ Se forem considerados isoladamente os dados relativos às empresas que empregam de 100 a 249 funcionários é possível verificar que elas sofreram uma das reduções mais drástica, pois perderam ao longo da década $81,1 \%$ do total de postos de trabalho existentes em 1990. 
Angela Carneiro Araújo, Elaine Aguiar Amorim

Tabela 1

\begin{tabular}{|c|c|c|c|c|c|c|c|c|c|c|c|c|c|c|c|c|c|c|}
\hline \multicolumn{19}{|c|}{ Emprego Segundo Gênero e Tamanho de Empresa no Setor de Confecções - "Região de Campinas/SP" 1990-1998 } \\
\hline & \multicolumn{2}{|c|}{1990} & \multicolumn{2}{|c|}{1991} & \multicolumn{2}{|c|}{1992} & \multicolumn{2}{|c|}{1993} & \multicolumn{2}{|c|}{1994} & \multicolumn{2}{|c|}{1995} & \multicolumn{2}{|c|}{1996} & \multicolumn{2}{|c|}{1997} & \multicolumn{2}{|c|}{1998} \\
\hline & $\mathrm{M}$ & $\mathrm{F}$ & M & $\mathrm{F}$ & $\mathrm{M}$ & $\mathrm{F}$ & M & $\mathrm{F}$ & $\bar{M}$ & $\mathrm{~F}$ & $M$ & $\mathrm{~F}$ & $\mathrm{M}$ & $\mathrm{F}$ & $\mathrm{M}$ & $\mathrm{F}$ & $M$ & $\mathrm{~F}$ \\
\hline Até 19 & 347 & 1143 & 348 & 989 & 268 & 918 & 300 & 1100 & 160 & 895 & 143 & 796 & 162 & 835 & 194 & 859 & 170 & 891 \\
\hline $\begin{array}{c}\text { De } 20 \\
\text { a } 49\end{array}$ & 215 & 541 & 233 & 715 & 153 & 517 & 143 & 562 & 123 & 600 & 108 & 601 & 80 & 535 & 151 & 474 & 104 & 320 \\
\hline $\begin{array}{c}\text { De } 50 \\
\text { a } 99\end{array}$ & 302 & 1043 & 125 & 276 & 225 & 556 & 111 & 543 & 78 & 621 & 92 & 376 & 99 & 421 & 113 & 517 & 84 & 417 \\
\hline $\begin{array}{c}\text { De } 100 \\
\text { a } 249\end{array}$ & 347 & 698 & 250 & 549 & 352 & 461 & 453 & 752 & 148 & 512 & 147 & 89 & 120 & 196 & 106 & 94 & 102 & 96 \\
\hline $\begin{array}{c}\text { De } 250 \\
\text { a } 499\end{array}$ & 328 & 264 & 618 & 335 & 473 & 293 & 239 & 123 & 216 & 114 & 276 & 210 & 237 & 160 & 210 & 138 & 188 & 109 \\
\hline $\begin{array}{c}\text { Mais de } \\
500\end{array}$ & 304 & 207 & 0 & 0 & 0 & 0 & 351 & 211 & 315 & 232 & 0 & 0 & 0 & 0 & 0 & 0 & 0 & 0 \\
\hline Total & 1843 & 3896 & 1574 & 2864 & 1471 & 2745 & 1597 & 3291 & 1040 & 2974 & 766 & 2072 & 698 & 2147 & 774 & 2082 & 648 & 1833 \\
\hline & \multicolumn{2}{|c|}{5739} & \multicolumn{2}{|c|}{4834} & \multicolumn{2}{|c|}{4216} & \multicolumn{2}{|c|}{4888} & \multicolumn{2}{|c|}{4014} & \multicolumn{2}{|c|}{2838} & \multicolumn{2}{|c|}{2945} & \multicolumn{2}{|c|}{2856} & \multicolumn{2}{|c|}{2481} \\
\hline
\end{tabular}

Fonte: Banco de Dados RAIS - Instituto Brasileiro de Geografia e Estatística. 
Redes de subcontratação

Quanto à composição da força de trabalho por gênero, os dados da tabela 1 confirmam o emprego majoritário das mulheres no ramo da confecção, mas também mostram que sua participação em relação à participação masculina por tamanho de empresa se alterou ao longo da década. As mulheres trabalhadoras tendem a se concentrar nas empresas com até 99 funcionários, nas quais constituem, em 1998, 82\% da força de trabalho, enquanto os homens eram maioria desde 1990 nas empresas com mais de 250 trabalhadores. Cabe destacar, que o processo de enxugamento realizado, no decorrer da década, nas empresas de porte médio (de 100 a 499 empregados) atingiu principalmente as mulheres. Elas foram demitidas em maior proporção do que os homens, que aumentaram sua participação de 55\% em 1990 para 63\% em 1998, nas empresas com 250 a 499 funcionários, e de $33,2 \%$ para $51,5 \%$, no mesmo período, nas empresas com 100 a 249 funcionários.

Esta distribuição dos trabalhadores por gênero pode indicar que o setor de confecção tende a substituir a força de trabalho feminina pela masculina nas empresas que passam por um processo de modernização tecnológica ou gerencial, como já foi observado no setor têxtil $e$ em outros. ${ }^{27} \mathrm{Em}$ contraposição, as mulheres se concentraram ainda mais nos trabalhos subcontratados, desregulamentados e precarizados, como podem ser caracterizados, em grande parte, o trabalho nas empresas prestadoras de serviços ou nas oficinas domiciliares.

\footnotetext{
${ }^{27}$ Amorim, Elaine R. A. e ARAÚso, Angela. M.C. O Trabalho Feminino no Novo Paradigma Produtivo: Uma Análise das Trabalhadoras das Indústrias Têxteis e do Vestuário de Campinas e Americana. Relatório Final apresentado à Fundação de Amparo à Pesquisa no Estado de São Paulo (FAPESP), Campinas, Unicamp, 1999; RIZEK, C. S. e LEITE M. de P. Dimensões e representações do trabalho fabril feminino. Cadernos Pagu (10), Núcleo de Estudos de Gênero - Pagu/Unicamp, 1998, pp.281-307.
} 
Tabela 2

\begin{tabular}{|c|c|c|c|c|c|c|c|c|c|c|c|c|c|c|c|c|c|c|}
\hline \multicolumn{19}{|c|}{ Emprego Segundo Gênero e Faixas de Renda no Setor de Confecção - "Região de Campinas/SP" -1990-1998 } \\
\hline & \multicolumn{2}{|c|}{1990} & \multicolumn{2}{|c|}{1991} & \multicolumn{2}{|c|}{1992} & \multicolumn{2}{|c|}{1993} & \multicolumn{2}{|c|}{1994} & \multicolumn{2}{|c|}{1995} & \multicolumn{2}{|c|}{1996} & \multicolumn{2}{|c|}{1997} & \multicolumn{2}{|c|}{1998} \\
\hline & $\mathrm{M}$ & $\mathrm{F}$ & $\mathrm{M}$ & $\mathrm{F}$ & $\mathrm{M}$ & $\mathrm{F}$ & M & $\mathrm{F}$ & $\mathrm{M}$ & $\mathrm{F}$ & $\mathrm{M}$ & $\mathrm{F}$ & $\mathrm{M}$ & $\mathrm{F}$ & $M$ & $\mathrm{~F}$ & $M$ & $\mathrm{~F}$ \\
\hline Até $1 \mathrm{SM}$ & 23 & 59 & 16 & 48 & 5 & 51 & 27 & 117 & 22 & 90 & 12 & 21 & 5 & 13 & 3 & 10 & 15 & 10 \\
\hline $\begin{array}{l}\text { De } 1,01 \text { a } \\
3 S M\end{array}$ & 852 & 3315 & 744 & 2474 & 588 & 2319 & 773 & 2904 & 376 & 2501 & 246 & 1711 & 252 & 1820 & 287 & 1678 & 250 & 1505 \\
\hline $\begin{array}{l}\text { De 3,01 a } \\
5 \mathrm{SM}\end{array}$ & 509 & 366 & 513 & 236 & 590 & 282 & 545 & 196 & 369 & 242 & 324 & 209 & 275 & 246 & 309 & 319 & 250 & 244 \\
\hline $\begin{array}{l}\text { De 5,01 a } \\
7 \text { SM }\end{array}$ & 255 & 67 & 158 & 47 & 158 & 34 & 136 & 34 & 139 & 57 & 58 & 34 & 59 & 33 & 53 & 35 & 60 & 39 \\
\hline $\begin{array}{l}\text { De } 7,01 \text { a } \\
10 \text { SM }\end{array}$ & 107 & 23 & 72 & 9 & 75 & 4 & 63 & 10 & 76 & 42 & 65 & 22 & 64 & 25 & 73 & 29 & 42 & 24 \\
\hline $\begin{array}{l}\text { De 10,01 a } \\
20 \text { SM }\end{array}$ & 61 & 7 & 50 & 5 & 33 & 2 & 31 & 2 & 32 & 17 & 33 & 7 & 29 & 5 & 36 & 4 & 22 & 5 \\
\hline $\begin{array}{l}\text { Mais de } \\
20,1 S M\end{array}$ & 7 & 1 & 8 & 2 & 6 & 1 & 7 & 0 & 18 & 0 & 19 & 1 & 12 & 0 & 12 & 3 & 8 & 2 \\
\hline Ignorado & 29 & 58 & 13 & 43 & 16 & 52 & 15 & 28 & 8 & 25 & 9 & 7 & 2 & 5 & 1 & 4 & 1 & 4 \\
\hline
\end{tabular}

Fonte: Banco de Dados RAIS - Instituto Brasileiro de Geografia e Estatística. 
Redes de subcontratação

As desigualdades entre trabalhadores e trabalhadoras no setor de confecção pode ser medida também pela diferença salarial. Cabe observar, primeiramente, pela Tabela 2, que a grande maioria dos trabalhadores neste setor, cerca de $71 \%$, está concentrada na faixa salarial de 1 a 3 salários mínimos e esta porcentagem não se alterou substantivamente ao longo da década. ${ }^{28} \mathrm{O}$ contraste entre homens e mulheres nesta faixa salarial como nas demais, no entanto, é brutal. Na faixa de 1,1 a 3 salários mínimos encontravam-se $85 \%$ das mulheres empregadas no setor em 1990 e 82,1\% em 1998. Enquanto 46,2\% dos homens em 1990 e 38,5\% em 1998 recebiam esta faixa salarial. É possível perceber que há uma melhor distribuição dos homens entre as diferentes faixas salariais, enquanto as mulheres permanecem concentradas na faixa inferior. Observa-se, também, que ao longo da década houve um ligeiro aumento do número de mulheres, que passaram de 11,7\% em 1990 a 16,5\% em 1998, nas faixas intermediárias entre 3 e 10 salários mínimos.

No entanto, a defasagem entre os homens e mulheres nas faixas superiores é gritante. Na faixa salarial superior a 10 salários mínimos, $0,3 \%$ das mulheres e 4,6\% dos homens estavam empregados no setor em 1998. Mas em relação ao total de trabalhadores recebendo nesta faixa, as mulheres correspondiam a $10,5 \%$ em 1990 e a 18,9\% em 1998, enquanto os homens correspondiam respectivamente a $89,5 \%$ e $81,1 \%$, demonstrando a predominância masculina nos postos hierárquicos mais elevados $e$ principalmente nos cargos de direção.

Todas essas características revelam não só a permanência, mas o reforço da divisão sexual do trabalho no setor de confecção. A diferença salarial entre trabalhadoras e trabalhadores que têm ocupações semelhantes é apenas um dos elementos que tradicionalmente fortalecem a exclusão social e econômica das mulheres. Se, ainda hoje, a continuidade dessas desigualdades

${ }^{28}$ No entanto, ocorreu uma redução importante no número de trabalhadores recebendo menos que 1 salário mínimo 
está presente nos empregos formais, é possível encontrá-las fortemente realçadas nas empresas que atuam na informalidade, visto que, nestas, a ausência de qualquer regulamentação trabalhista leva à imposição de condições precárias de trabalho.

Além da divisão sexual do trabalho encontramos no setor de confecção uma divisão sexual da propriedade que reproduz a assimetria entre os sexos. Na região de Campinas, as empresas de pequeno e médio porte, que produzem diretamente para o mercado e não realizam produção subcontratada, têm, em geral, homens como seus proprietários, enquanto encontramos mulheres como proprietárias e dirigentes nas oficinas de costuras que atuam apenas como subcontratadas. Estas, na maioria dos casos, surgiram a partir do trabalho a domicílio realizado por suas proprietárias e estão fortemente marcadas pela instabilidade das relações informais e pelos riscos a elas transferidos pelas empresas contratantes.

\section{O processo de reestruturação das empresas de confecção}

Diante da dificuldade de competir no mercado brasileiro com produtos importados de melhor qualidade e menor preço, as empresas confeccionistas da Região de Campinas iniciaram um processo de ajuste, adotando diferentes estratégias de "sobrevivência".

No processo de reorganização da produção desencadeado pelas empresas a partir dos anos 90 , a modernização do aparato produtivo não se constituiu como uma estratégia de aumento da produtividade e de melhoria da qualidade. Como a maioria das empresas produz para a indústria da moda, a ausência de investimentos em inovações tecnológicas é justificada pelos empresários pela insuficiência de capital necessário e pela dificuldade de aproveitar plenamente a capacidade dos novos equipamentos em um processo produtivo voltado para uma produção em pequena escala e muito variada. 
Redes de subcontratação

Algumas empresas, no entanto, chegaram a introduzir equipamentos de base microeletrônica de forma pontual, principalmente nos setores de design, modelagem e encaixe. $\mathrm{Na}$ empresa "L", que produz artigos masculinos de diferentes tamanhos, procurando atender também à demanda de roupas para obesos, foi introduzido um sistema computadorizado no setor de modelagem e encaixe que, além de aumentar a produtividade nesta área, contribuiu para reduzir o desperdício de tecido. $\mathrm{Na}$ empresa "V", que confecciona camisas masculinas, uma máquina de base microeletrônica foi introduzida no setor de acabamento, com o objetivo de eliminar um gargalho do fluxo da produção. No entanto, o uso pontual de equipamentos modernos pode criar dificuldades ao acarretar um descompasso no ritmo da produção. Como observou o gerente de "V", o novo equipamento tem um ritmo de produção extremamente elevado, que não pode ser acompanhado pelas máquinas antigas e tem grande parte de sua capacidade produtiva ociosa. Esta ociosidade dificultou a introdução de outras máquinas, como estava planejado inicialmente, pois o alto investimento exigido para a compra de cada equipamento não é compensado por um aumento substancial da produtividade.

A dificuldade de investir em tecnologia não levou, no entanto, as empresas da região a priorizar os novos métodos de gestão como forma de aumentar a produtividade. Assim como verificado por Versiani e Gaspar ${ }^{29}$ nas pequenas empresas do setor em Belo Horizonte, nas entrevistas que realizamos com empresários em Campinas percebemos um conhecimento muito superficial em alguns casos e praticamente nulo em outros com relação às inovações organizacionais e sua relação com o aumento de produtividade e com a melhoria de qualidade dos produtos. Na maior parte das empresas predominam métodos tradicionais de gestão e processos de trabalho baseados em postos fixos e na realização de tarefas manuais e repetitivas.

${ }^{29}$ Versiani, A. F. e GASPAR, R. M. Diferenças e similaridades... Op. cit. 
Em algumas das confecções pesquisadas, no entanto, encontramos um processo de reorganização da produção que combinava elementos dos novos modelos de gestão com outros típicos do trabalho taylorizado. Na empresa "V", especializada na produção de camisas masculinas, foi introduzido um novo sistema de gestão da produção baseado no trabalho em equipes. $\mathrm{O}$ conteúdo das tarefas não sofreu alteração, mas o trabalho tornouse mais eficiente e controlado, através da adoção do cronômetro como instrumento de controle do tempo de produção e de uma política de envolvimento e de transferência de responsabilidades às trabalhadoras. $\mathrm{O}$ novo sistema consistiu na divisão da principal fase do processo produtivo, a costura, em nove times $e$ na introdução de carrinhos que controlavam o fluxo da produção ao se dirigirem de um time para outro a cada meia hora. Como cada time costurava uma parte da camisa, a alocação das costureiras em cada um deles ocorreu a partir de um estudo do tempo gasto por elas na confecção das diversas partes. Desse modo, no intervalo de meia hora, as costureiras do $1^{\circ}$ time deveriam passar para $\circ 2^{\circ}$ (e assim sucessivamente) o carrinho com as peças costuradas, pois neste mesmo instante recebiam do setor de corte um outro carrinho com novas peças cortadas.

Este sistema permite à gerência visualizar com facilidade quando o fluxo da produção está parado ou lento, em função do atraso na passagem do carrinho de um time para outro. O tempo controlado pela passagem do carrinho pressiona a trabalhadora que não está conseguindo acompanhar o ritmo do grupo. Além disto, para incentivar e controlar a produtividade e a qualidade do trabalho, a empresa estabeleceu metas que devem ser alcançadas diariamente e uma avaliação feita também diariamente, através de um sistema de pontuação, tanto do desempenho dos times quanto de cada trabalhadora individualmente. $\mathrm{O}$ alcance das metas $e$ as pontuações mais altas são recompensadas com um prêmio de produtividade, que corresponde a um pequeno aumento no salário (que varia de 0,50 a 1,50 reais) mensal. Este novo método de gestão gera formas de pressão individual e coletiva que levam 
Redes de subcontratação

as trabalhadoras a se preocuparem com a qualidade e com o aumento do ritmo de produção, seja através de sugestões ou da extensão da jornada de trabalho em horários fora do expediente, em geral não remunerados.

A experiência de mudanças de "V" pode ser tomada como um exemplo do tipo de reestruturação que vem sendo desenvolvida no setor de confecção. Principalmente nas pequenas $e$ médias empresas se observa a combinação de práticas tayloristas, de tarefas parcelares e repetitivas, com algumas técnicas associadas às novas formas de gestão geralmente introduzidas com o objetivo e aumentar a produtividade através do aumento do ritmo do trabalho e da redução dos tempos mortos.

As mudanças ocorridas no interior das empresas decorrentes da redução do número de funcionários e da combinação entre antigos e novos sistemas de gestão, onde ela ocorreu, tiveram impacto importante sobre as condições de trabalho dos que permaneceram empregados. É comum no depoimento dos/as trabalhadores/as entrevistados/as a percepção da pressão pelo cumprimento das metas de produção, do aumento da intensificação do ritmo de trabalho $e$ da transferência das responsabilidades para eles/as.

Se você tem um compromisso com esse sistema novo ${ }^{30} \mathrm{de}$ "V", você tem um compromisso com o horário, você precisa cumprir tantas peças (...) Essa responsabilidade foi transferida prá própria costureira. (...) A responsabilidade de [fazer] determinada quantidade em determinado tempo já foi transferida prá própria costureira, porque o patrão já não está arcando sozinho com aquela responsabilidade. (Lígia, costureira da empresa "V")

Eu acho que hoje a gente trabalha mais. (...) pela redução do pessoal, você trabalha mais, produzindo menos. Naquele tempo não, você tinha uma seção de corte grande,

${ }^{30}$ A funcionária se refere ao novo sistema de gestão implantado pela empresa. 
Angela Carneiro Araújo, Elaine Aguiar Amorim

então você produzia mais, trabalhando até menos e hoje você trabalha mais e produz menos.

(Graciliano, encarregado do setor de corte da empresa " $\mathrm{R}$ ")

Em relação ao perfil do conjunto de trabalhadores/as contratados/as formalmente é possível observar alguns traços comuns. Em geral, predominam no setor de confecção os trabalhadores com primeiro grau completo. As mulheres constituem a principal força de trabalho e, entre elas, as jovens mais escolarizadas (cursando ou já tendo o segundo grau completo) são contratadas como auxiliares de produção $e$ predominam nos postos de trabalho em que as atividades são mais repetitivas e manuais (como no setor de acabamento ou embalagem), recebendo, em geral, em torno de um salário mínimo.

Prevalece, entre os pequenos e médios empresários do setor, uma visão conservadora com relação à gestão da mão-deobra e mais especificamente em relação às habilidades $e$ qualificações necessárias hoje à produção $e$ ao emprego do trabalho feminino. Embora todos os proprietários entrevistados aleguem dificuldade em encontrar trabalhadoras qualificadas, principalmente costureiras experientes, eles não oferecem cursos de qualificação e consideram o aprimoramento de novas habilidades como um dever de cada funcionária, resultado do seu interesse e empenho. ${ }^{31}$ É curioso que, em geral, os empresários e gerentes, apesar de não fornecerem qualquer forma de treinamento, nem os de conteúdo comportamental, destacaram como parte dos seus critérios de recrutamento e de suas exigências, em relação aos/às trabalhadores/as, atitudes como capacidade de iniciativa, disposição de aprender novas tarefas, capacidade de realizar mais de uma tarefa (polivalência) - mesmo

${ }^{31}$ Como mostra este depoimento do gerente administrativo de "V": "(...) tem gente aí na fábrica que pede prá ficar, fala assim: 'W.C, se você não se importar a gente gostaria de ficar aí um pouquinho, uns 15 minutos a mais, prá ficar testando habilidades...' nossa, isso é bom demais e a gente tá valorizando isso". 
Redes de subcontratação

que nem sempre estas atitudes sejam requeridas de fato pelo tipo de organização do trabalho mantido no chão de fábrica. ${ }^{32}$ Principalmente em relação às mulheres, nem as novas atitudes nem as qualificações tradicionais das costureiras são percebidas como merecedoras de incentivos e remuneração adequadas. Como a principal atividade realizada por elas no setor de confecção, a costura exige um saber tradicionalmente adquirido no espaço doméstico, ele nem sempre é reconhecido pelos empresários como uma qualificação técnica. Além disto, o perfeccionismo, a precisão, a delicadeza, que justificam, muitas vezes, a preferência destes empresários pela contratação de mulheres, são características vistas como femininas "por natureza", e não como habilidades ou competências específicas que deveriam ser valorizadas.

A tendência que observamos neste setor é, portanto, a de que as empresas procuram recrutar mulheres jovens mais escolarizadas, mas que são consideradas sem qualificação $e$ empregadas em tarefas simples e repetitivas, e costureiras experientes, mas que, em geral, tem um menor grau de escolaridade, e cuja qualificação técnica não é reconhecida como tal nem remunerada de forma condizente. As empresas pagam salários baixos que não correspondem à escolaridade $e$ à produtividade exigidas das auxiliares de produção $e$ das costureiras $^{33}$ e não concedem benefícios além dos estipulados na convenção coletiva anual da categoria, que, normalmente, garante

\footnotetext{
${ }^{32}$ Com exceção da empresa "V", que com a implantação do novo sistema de gerenciamento da produção passou a exigir estas atitudes das funcionárias e inclusive a capacidade de executar mais de uma tarefa de modo a ajudar outros membros do mesmo time.

${ }^{33} \mathrm{Na}$ empresa "L" - que pode ser tomada como um exemplo do padrão salarial predominante no setor - a porcentagem de trabalhadores em cada faixa salarial era de $39,3 \%$ até 1 salário mínimo, $52,4 \%$ de 2 a 3 salários, 3,6\% de 4 a 5 salários e 4,7\% acima de 5 salários. É importante lembrar que dos/as 84 trabalhadores/as contratados/as havia 76 mulheres e 8 homens e a esmagadora maioria das mulheres não recebia mais de 3 salários mínimos.
} 
Angela Carneiro Araújo, Elaine Aguiar Amorim

apenas o mínimo já estabelecido em lei. Além disto, remuneram desigualmente homens e mulheres, mesmo os que têm qualificações e responsabilidades equivalentes.

Qualquer proposta de melhoria salarial é vista com muita resistência. Como argumenta um gerente a respeito do aumento de $2 \%$ dos salários obtido pelas funcionárias em 1998 :

(...) o aumento salarial tem que ser revisto, porque hoje o poder aquisitivo de quem está empregado aumentou... Eu posso falar com absoluta certeza, com conhecimento de causa, que o salário da minha menina, da minha costureira que trabalhava na fábrica há 4 anos atrás, $e$ hoje, ela tem poder de compra, de sobrevivência, porque o salário delas é de sobrevivência, muito melhor, mas muito melhor mesmo. ${ }^{34}$ Tem uma economia estável, que não aumenta nada, que não tem inflação... o comércio $e$ a indústria com reduções brutais de margem, não tem justificativa de aumento salarial. Então, eu acho que $2 \%$ foi muito mesmo, e eu acho que o ano que vem [1999] não tem que ter, não tem que ter... Ah! Eu sou malvado! Não, é a realidade! Hoje $2 \%$ é um grande aumento.

(W.C., gerente administrativo da empresa "V")

Em todas as empresas por nós pesquisadas, com exceção apenas de "V"35, a subcontratação foi utilizada como elemento central de uma estratégia de sobrevivência e de recuperação da

${ }^{34}$ Os salários das funcionárias correspondem aproximadamente a $\mathrm{R} \$ 300,00$ (costureira) e $\mathrm{R} \$ 180,00$ (auxiliares).

${ }^{35}$ No caso de "V", que produz para um mercado de classe média e entrega diretamente seus produtos para a venda no varejo (lojas de "grife" em geral nos shopping centers da região), houve em meados da década de 90, uma experiência de terceirização de parte importante da sua produção. Mas devido a perda de clientes que alegavam insatisfação com a qualidade dos produtos, ela voltou a internalizar a produção e adotou como estratégia central para a recuperação da competitividade o novo sistema de gestão da produção acima descrito, que permitiu um aumento importante da produtividade com redução de custos. 
Redes de subcontratação

sua capacidade de competir. A subcontratação não representa propriamente uma novidade nesse ramo, pois ele tradicionalmente utilizou o trabalho de costureiras externas, especialmente nos momentos de pico da produção. Porém, no contexto de um mercado globalizado que estabelece novas condições de concorrência, a terceirização e o trabalho a domicílio são revitalizados e utilizados de forma mais intensa pelas empresas de confecção com o objetivo de redução de custos e aumento da produtividade.

As atividades geralmente externalizadas são a costura, o acabamento e a embalagem. As empresas tendem a manter internamente as fases do design, da modelagem, encaixe e corte que definem as características do produto $e$ a terceirizar as fases da produção intensivas em mão-de-obra. ${ }^{36} \mathrm{E}$ como em geral esta forma de subcontratação parcial visa fundamentalmente a redução de custos, ela é realizada através de contratos informais, e cria uma relação assimétrica de subordinação das empresas ou trabalhadores/as subontratados/as em relação às contratantes.

É interessante observar a teia de relações que envolvem a terceirização. Se tomarmos como referência o proprietário da pequena empresa " $\mathrm{R}$ ", notamos que ele subcontrata tanto para pequenas oficinas de $\operatorname{costura}^{37}$, que, muitas vezes, se igualam à sua empresa em relação ao porte e ao número de funcionários, quanto para trabalhadoras a domicílio, entretanto, ele diferencia o tipo de serviço que destina a cada uma delas. Para as primeiras ele repassa a costura das camisas para adultos, enquanto para as costureiras domiciliares ele transfere a confecção completa da linha infantil masculina, que inclui costura e acabamento. Neste

\footnotetext{
${ }^{36}$ Não verificamos em nenhuma empresa e na bibliografia pesquisada casos de repasse do setor de corte e de modelagem, embora tenhamos entrevistado um trabalhador que prestava serviços de corte para pequenas lojas de confecção.

${ }^{37}$ Por exemplo, a empresa subcontratada "A" apresentava melhores condições de instalação e duas máquinas de costura modernas que não se verificavam na sua contratante "R".
} 
caso, cada costureira recebe as peças cortadas e devolvem, no prazo estipulado, as roupas prontas.

A terceirização foi também empregada por estas empresas como forma de diversificar sua produção, com o objetivo de conquistar novas fatias do mercado menos competitivas e pouco atingidas pelos produtos importados. O que chama atenção na introdução das novas linhas de produto é que foram criadas para serem confeccionadas por "unidades produtivas" externas, ou seja, por empresas subcontratadas e costureiras domiciliares, de modo a evitar o investimento em novas máquinas e novas contratações.

Assim como "R" o fez com a linha de roupas infantis, a empresa "L", especializada na confecção de calças e camisas masculinas, decidiu ampliar sua produção com uma nova linha de pijamas e cuecas inteiramente terceirizada. O êxito obtido com a redução dos custos na produção das novas linhas ${ }^{38}$ levou o proprietário a planejar um investimento ainda maior, e a curto prazo, na confecção de cuecas, pois pretende, pelo uso intensivo da terceirização, tornar-se um concorrente em potencial de uma marca reconhecida e mais vendida no país.

A terceirização tem sido, portanto, utilizada por estas empresas como a principal estratégia de competitividade. Pois além de permitir o aumento e diversificação da produção com redução significativa dos gastos produtivos e com os encargos trabalhistas, por estar baseada em contratos informais representa uma transferência de riscos (principalmente os decorrentes das flutuações na demanda - comum neste seguimento) da empresa contratante para as oficinas e costureiras subcontratadas, que já atuam nas margens do mercado de trabalho e, em muitos casos, tem dificuldade de encontrar alternativas de reinserção.

${ }^{38} \mathrm{O}$ proprietário de "L" pesquisa continuamente a existência de oficinas que possam garantir preços mais baixos. No período da pesquisa, ele declarou que pagava $\mathrm{R} \$ 0,30$ e $\mathrm{R} \$ 0,50$ para confeccionar, respectivamente, cuecas tipo "sliper" e "samba canção", mas que já havia pago anteriormente $\mathrm{R} \$ 0,80$ e $\mathrm{R} \$$ 0,90 para uma outra empresa subcontratada. 
Redes de subcontratação

\section{As empresas subcontratadas}

O estudo das cadeias produtivas tem possibilitado a identificação de distintas formas de trabalho subcontratado $e$ a existência de indivíduos e grupos de trabalhadores/as, cuja inserção no mercado de trabalho se dá sob novas condições. No setor de confecção, as empresas subcontratadas e o trabalho a domicílio têm em comum sua subordinação às determinações das empresas contratantes, mas são diferentes quanto ao grau de precarização e de vulnerabilidade que demarcam suas relações de trabalho. Embora seja uma prática comum dos empregadores ocultar essas "unidades produtivas" externas ao espaço fabril - em função do caráter precário do trabalho ali desenvolvido -, ao longo da pesquisa foi possível identificar uma rede de subcontratação localizada em diferentes cidades da região de Campinas, composta por empresas de diferentes tamanhos e o predomínio do uso do trabalho a domicílio, tanto diretamente pelas contratantes, quanto pelas oficinas subcontratadas.

Nesta rede identificamos a presença de dois tipos de relação de subcontratação. No primeiro tipo estão duas oficinas de costura de pequeno porte, especializadas na confecção de camisas (Empresa "A") e de lingerie masculina (Empresa "E"), que se constituíram a partir do trabalho a domicílio de suas proprietárias, e do aumento da demanda por serviço subcontratado. Por isso, é comum encontrar mulheres na direção dessas oficinas, ao contrário do que é verificado normalmente nas empresas contratantes, nas quais encontramos proprietários e gerentes do sexo masculino.

A relação com as contratantes se estabelece através de um "vínculo informal", pois a maior parte delas preferem não firmar um contrato de prestação de serviços, o que provavelmente acarretaria o compromisso de transferir continuamente um determinado volume de produção. Esta informalidade, e o fato desta relação envolver a subcontratação parcial de uma fase do processo produtivo que pode ser facilmente transferida de uma 
oficina para outra, expõe as empresas subcontratadas a uma pressão constante pela redução de preços $e$ a um alto grau de instabilidade, pois as contratantes podem romper com o vínculo a qualquer momento. Em alguns casos, o rompimento do vínculo pode acarretar a devolução de máquinas emprestadas, a demissão de funcionários/as, o fechamento da empresa e até mesmo o retorno da proprietária ao trabalho a domicílio, como foi ocorreu no caso da empresa "E". ${ }^{39}$

Como foram formadas a partir do trabalho a domicílio, o aparato produtivo dessas oficinas é, em grande parte, obsoleto, composto por máquinas adquiridas de segunda-mão $e$, em alguns casos, emprestadas pelas contratantes. Elas não conseguem, portanto, acompanhar as inovações tecnológicas existentes no setor, em função das limitações financeiras que as impedem de realizar investimentos. Isto se verifica também no emprego de novas formas de gestão. Nas oficinas pesquisadas a mudança na forma de organização da produção se dá lentamente e até mesmo de maneira intuitiva, conforme o aumento do volume da produção passa a exigir um controle maior sobre o processo produtivo. Na empresa "A", por exemplo, a modificação na forma de organizar a produção deu-se a partir de conversas informais o com gerente da empresa contratante e de visitas a outras empresas e ocorreu de modo a racionalizar o processo produtivo através do aprofundamento da simplificação e fragmentação das

\footnotetext{
${ }^{39}$ Costurando cuecas para uma única empresa, que lhe emprestava a maior parte do maquinário, esta oficina conseguiu aumentar sua produção entre os anos de 1993 e 1997 quando manteve 7 funcionárias e subcontratou o trabalho de 23 costureiras externas. No entanto, no final de 1997, a contratante rompeu os vínculos "informais" com esta terceira, parando de lhe fornecer serviços e recolhendo as máquinas emprestadas. A proprietária de "E" teve que demitir todas as funcionárias e voltar ao trabalho domiciliar. Conseguiu, no entanto, reerguer a empresa, passando a ser subcontratada por outros clientes. Adquiriu máquinas via empréstimo bancário e diversificou sua produção a partir da confecção de cuecas "sliper" e da embalagem. Desse modo, em 1999 esta oficina já contratava 18 funcionárias e repassava trabalho para 32 costureiras domiciliares.
} 
Redes de subcontratação

tarefas, na especialização das costureiras na realização de apenas uma tarefa simples, no mais tradicional estilo taylorista.

$\mathrm{Na}$ tentativa de fazer face à instabilidade inerente à relação de subcontratação, estas oficinas, em geral, passaram a adotar como estratégia, a especialização na costura de um ou de poucos artigos, a prestação de serviços para várias empresas contratantes e o uso freqüente do trabalho a domicílio, para o qual é transferida parte das encomendas recebidas, como forma de eliminar custos com a produção e reduzir o preço cobrado por peça.

A força de trabalho nas oficinas de costura é constituída por uma maioria esmagadora de mulheres (de $95 \%$ a 100\%), que perderam seus empregos em empresas que fecharam suas portas ou reduziram o número de funcionários e têm, por isto, um perfil muito semelhante ao encontrado nas empresas contratantes. Estas trabalhadoras ainda que sejam registradas, não tem assegurado alguns benefícios e direitos trabalhistas (como por exemplo, valetransporte e descanso de 15 minutos em cada período do dia), além de receberem salários inferiores, mas que seguem de perto aqueles pagos nas empresas contratantes. O domínio da costura da peça inteira não é uma exigência primordial no recrutamento dessas trabalhadoras, mas, sobretudo, a habilidade na realização de determinada tarefa, já que ela garante rapidez e maior produtividade - o principal fator de competitividade dessas empresas.

O segundo tipo de relação de subcontratação encontrado na região aproxima-se da forma de subcontratação completa, mas equivalente. Ela se estabelece entre uma grande empresa têxtil ("T"), especializada em artigos de cama, mesa e banho concorrente de importantes marcas do ramo - que decidiu terceirizar seu setor de confecção e uma empresa de porte médio, "F", que tinha 500 funcionários em 1999 e foi formada especialmente para produzir os artigos de cama e mesa para "T". A implantação de "F" foi precedida de um estudo acerca da estrutura física, do porte e da localização ideais para se atender as 
exigências da contratante e se efetivou com a contratação de funcionários e gerentes demitidos por ela. "T" estabeleceu um contrato formal com "F" e transferiu para a subcontratada as inovações gerenciais por ela introduzidas, como por exemplo, o sistema de células.

Em " $F$ " foram introduzidas sete células na fase do processo produtivo que corresponde à costura, tendo cada uma delas cerca de 13 costureiras, responsáveis pela produção e revisão de um determinado produto (por exemplo, uma célula faz o lençol sem elástico e a outra o lençol com elástico), no prazo programado. Vista como uma forma de garantir os níveis de produtividade e de qualidade requeridos pela contratante, a incorporação do sistema de células proporcionou também uma redução dos custos, ao reduzir o desperdício e uma transferência de responsabilidades para as trabalhadoras, já que elas devem administrar o seu próprio trabalho e o de suas colegas. Conforme argumenta o responsável pelo PCP (Processos e Controle da Produção) da empresa:

As próprias pessoas que estão inseridas naquele grupo, elas se auto administram. Aí que começa a vantagem para a empresa. (...) E entre essas pessoas, se alguém começa a faltar, por um motivo ou outro começa a não produzir, não é a empresa, a supervisora que vai cortar, são as próprias colegas que cortam esta pessoa. (J.R.)

A reorganização do trabalho através das células é, portanto, valorizada pela gerência como uma forma de assegurar um maior envolvimento das funcionárias e conceder-lhes maior autonomia. Das trabalhadoras é exigido além do cumprimento das metas de produção programadas diariamente, o controle visual de qualidade, a realização de pequenas manutenções nas máquinas e a disposição de solucionar pequenos problemas técnicos $e$ operacionais. A multifuncionalidade neste caso significa a agregação de algumas tarefas muito simples e não rompe com o 
Redes de subcontratação

trabalho repetitivo. A "autonomia" concedida às trabalhadoras para realizar reuniões destinadas à solução de problemas não significa o reconhecimento do tempo despendido nestas reuniões como tempo produtivo, pois o que conta para a gerência é a produção da quantidade estipulada no fim do dia, como fica claro neste depoimento:

Se elas [funcionárias] acharem: "nós temos que parar para conversar porque tem alguma coisa que não está certa". Você pode passar na produção e perguntar: "mas o que é aquela rodinha? Elas estão discutindo o trabalho". Eu não quero saber, eu quero o resultado no final do dia... com qualidade. (D. M., diretor administrativo)

O sistema de células surge aqui fundamentalmente como um instrumento de elevação da produtividade e tem significado, na prática, a extensão da jornada de trabalho sem pagamento de horas extras, o aumento do ritmo da produção $e$ o estabelecimento de uma nova forma de controle realizado pelas próprias trabalhadoras. Este sistema de gestão além de gerar cansaço físico, devido ao intenso ritmo da produção, provoca desgaste emocional devido à pressão coletiva exercida pela própria célula que se soma à exercida pela supervisão.

Nesta forma de subcontratação, o estabelecimento de um contrato formal e de quase exclusividade entre subcontratada $e$ contratante, assegura um menor grau de instabilidade à primeira, e permite a transposição de inovações gerenciais que, aliadas ao pagamento de menores salários e a não concessão de benefícios às/aos trabalhadoras/es, garantem, de um lado, o padrão de qualidade e, de outro, uma elevada produtividade a baixos custos, que torna a continuidade da relação vantajosa para a empresa cliente. 
Angela Carneiro Araújo, Elaine Aguiar Amorim

\section{O trabalho a domicilio}

$\mathrm{Na}$ rede de subcontratação que identificamos na região de Campinas o trabalho a domicílio desempenha um papel central enquanto parte da estratégia de um conjunto empresas de pequeno e médio porte de aumento e diversificação da produção a baixo custo. $O$ trabalho realizado no espaço doméstico por costureiras é utilizado pelas empresas confeccionistas da região, que transferem, para elas, a costura de seus principais produtos ou a confecção de linhas inteiras de novos produtos, entregando as peças cortadas $e$ os insumos necessários à costura $e$ ao acabamento. Neste caso, as empresas buscam usufruir o trabalho de costureiras mais qualificadas, que têm habilidade e experiência para confeccionar peças inteiras, sem ter que arcar com o pagamento de salários maiores e com os encargos trabalhistas.

A lógica da subcontratação é a de que o contratante aumenta sua produtividade e lucros em grande medida ao transferir para as empresas subcontratadas os custos de aquisição, manutenção do maquinário e os encargos da contratação da mãode-obra e parte dos riscos do negócio. Assim, para assegurar maior produtividade e faturamento, as subcontratadas acabam tendo que subcontratar também informalmente o trabalho de costureiras a domicílio, pagando-lhes por peça uma parcela ainda menor do que aquela que recebem da empresa contratante. Esta lógica leva à transferência do ônus da produção sempre para os níveis mais frágeis da cadeia.

Apesar de serem consideradas como trabalhadoras autônomas pelas empresas contratantes, a ausência de contrato formal $e$ o fato das costureiras estarem totalmente subordinadas às condições, prazos e formas de pagamento impostos, configura uma relação de emprego precária, estabelecida na informalidade para escapar da regulamentação e dos encargos legais. As costureiras domiciliares ocupam a ponta inferior desta "cadeia de subordinação e exploração" e estão submetidas a vínculos precários com as contratantes, ao pagamento por peça a preços 
Redes de subcontratação

muito baixos e a uma instabilidade permanente, devido ao fato de que as contratantes detêm o poder unilateral de iniciar $e$ interromper o repasse de serviços. A elas são transferidos os ônus $e$ riscos envolvidos na produção.

A busca de redução de custos envolvida nos menores detalhes desta relação pode ser verificada no caso de uma das nossas entrevistadas que costurava para uma empresa terceirizada mantida pela produção de uniformes feitos por costureiras domiciliares. Esta empresa fornecia o tecido e as peças cortadas e descontava, do valor pago por peça produzida, as linhas utilizadas na costura. Esse desconto era justificado como uma medida de precaução da empresa, a fim de evitar que as costureiras se apropriassem do material fornecido. As linhas necessárias para a confecção eram pesadas no momento em que as peças eram repassadas à costureira e, quando esta entregava a produção final, calculava-se através de uma tabela o quanto deveria ser descontado. ${ }^{40}$

Todas as costureiras entrevistadas afirmaram a importância de se cumprir os prazos de entrega, a produção completa do número de peças repassadas e a qualidade do trabalho, caso contrário corriam o risco de terem o vínculo com o contratante rompido. Essas exigências associadas aos baixos valores pagos por peça impõem às trabalhadoras um ritmo de trabalho intenso $e$ a extensão da jornada de trabalho, que inclui finais de semana, feriados e o envolvimento de outros membros da família, como pode ser verificado nestes depoimentos:

${ }^{40} \mathrm{O}$ preço de cada uniforme correspondia em 1999 aproximadamente a $\mathrm{R} \$ 1,26$, do qual era descontado $\mathrm{R} \$ 0,08$ da linha. Como os preços variavam conforme o modelo do uniforme e como apenas a empresa tinha a tabela de controle do quanto se gastava para confeccionar cada peça, a costureira não conseguia controlar o seu próprio pagamento, ficando expostas a possíveis "erros" de cálculo. 
Angela Carneiro Araújo, Elaine Aguiar Amorim

Eu acordo todo dia 7:00 horas, no horário do almoço eu corro, qualquer hora que eu me levanto aqui eu corro lá dentro e corro prá máquina. (Edite)

A nossa vida é corrida, mas a dela é pior. Ela [Edite] não tem folga dia de sábado, não tem folga dia de domingo, não tem folga de feriado... (Laura)

Começo às 7:00 horas. Faço uma hora de almoço, às vezes faço uma hora e meia quando quero botar ordem na casa (...). Quando chega à tarde, a gente [ela e a filha] ${ }^{41}$ já pára mais uma hora, duas horas: lava o quintal, lava o carro, bota ordem nas outras partes de novo. Aí volta prá máquina de novo. Eu trabalho no domingo até umas dez horas, dez e meia. Eu começo oito horas só prá dar um empurrãozinho. (Augusta)

Como conseqüência deste trabalho sem descanso, estão presentes nos depoimentos destas trabalhadoras, relatos sobre o impacto negativo sobre suas condições de saúde.

Eu operada, menina, o véio [pessoa que repassa os serviços] chegou aqui com 60 bermudas, ninguém queria fazer, eu me sentei na máquina, tcháqui, tcháqui, tcháqui [imita o barulho da máquina], aquele sangue desceu, quando eu pensei que não, eu tava toda marcada de sangue, tudo. (Edite, 56 anos) ${ }^{42}$

Eu estava na máquina trabalhando, eu tinha que sair prá resolver problema de banco, aí no que eu saí, eu acabei batendo o carro. Porque (...) você costurar demais, parece

\footnotetext{
${ }^{41}$ Desde criança a filha de Augusta a ajuda na confecção das roupas. Quando Augusta saiu da firma em que trabalhava e começou a costurar na própria casa, adquiriu duas máquinas, uma para ela e outra para a filha.

${ }^{42}$ Este fato ocorreu quando Edite estava em estado de convalescência, se recuperando de uma cirurgia feita na região do estômago. Zuleika (costureira que trabalha na mesma oficina) esclarece o ocorrido ao complementar a fala de Edite: "Ela sentou na máquina antes de acabar a anestesia, depois foi acabando..."
} 
Redes de subcontratação

que ela [máquina] hipnotiza a cabeça da gente e quando você sai, parece que você tá fora de si. Eu saí com muita dor de cabeça, dava, inclusive, uma impressão que tudo tava balançando. (Augusta)

Eu já tive dor nas costas, problema de dor nas costas. O médico mandou eu me afastar duas semanas da máquina, só que no meu caso eu não fiquei parada da máquina; tomei o medicamento, continuando na máquina. (Laura)

A exploração das costureiras domiciliares se concretiza sob o respaldo da invisibilidade: elas não constam dos registros oficiais das empresas, nem das estatísticas industriais ou governamentais. $\mathrm{Na}$ medida em que exercem suas atividades produtivas no espaço não-fabril e em que se estabelece um "distanciamento" entre a empresa contratante e o processo de produção, estas se eximem e julgam que o fazem de forma legítima - da responsabilidade sobre o que possa ocorrer neste espaço produtivo $e$ às trabalhadoras envolvidas.

As costureiras por nós entrevistadas, no entanto, revelaram que mesmo diante das condições de trabalho, da instabilidade dos serviços e da ausência de direitos trabalhistas, elas preferem o trabalho a domicílio. As diferenças existentes entre elas quanto a qualificação, sua possibilidade de envolver um maior número de pessoas (familiares, vizinhas) no trabalho e, portanto, quanto a sua produtividade e remuneração, aparecem na avaliação que fazem das vantagens dessa forma de trabalho.

Para uma das entrevistadas o trabalho a domicílio é visto como uma atividade melhor remunerada que dá à costureira a possibilidade de se tornar uma empregadora e de ascender socialmente. Para outras, esta forma de trabalho configura-se como uma atividade pouco remunerada, porém, é uma alternativa para o desemprego ${ }^{43}$ e para os baixos salários predominantes nas

${ }^{43}$ Do total de oito costureiras domiciliares entrevistadas, cinco começaram a realizar esse tipo de trabalho por estarem desempregadas. 
Angela Carneiro Araújo, Elaine Aguiar Amorim

indústrias de confecção. Nesse sentido, o trabalho a domicílio representava uma forma de romperem com os obstáculos que as impediam de reingressar no mercado de trabalho devido sua idade ou sua qualificação $e$, principalmente, de garantir uma remuneração mínima.

Eu fiz um balanço: o que eu fiz em dois meses nesse ano passado, se eu trabalhasse numa firma, como costureira, o que eu fiz em dois meses, eu, de costureira, levaria um ano e três meses prá mim ganhar numa firma (...) mesmo que você fique dois meses parada, se você trabalhar dois meses, você recupera o que você trabalhou um ano em uma firma. Então você não pode falar, lamentar, reclamar. (Augusta)

Mais que numa fábrica de costura a gente consegue tirar, muito mais. (Luciana)

Está, contudo, ausente desta avaliação, apesar de presente em outros momentos da fala destas trabalhadoras, que a remuneração por elas conseguida é maior porque obtida através da inclusão de outros membros da família, da intensificação do ritmo e da extensão da jornada de trabalho, que inclui finais de semana e feriados, e pela ausência de direitos trabalhistas, entre eles, férias ou descanso semanal remunerado.

Desse modo, o trabalho a domicílio revela-se, na indústria de confecção no contexto atual, como uma forma de aumento dos ganhos de produtividade através da extração de mais valia absoluta, tendo em vista a dificuldade de alcançá-los através do investimento em capital fixo e da ampliação da mais valia relativa.

\section{Considerações finais}

A pesquisa realizada no setor de confecção na região de Campinas mostrou que, em resposta à crise vivenciada durante a década de 90, principalmente em decorrência das novas condições de concorrência estabelecidas com a abertura 
Redes de subcontratação

comercial, as empresas sobreviventes, em sua maioria empresas de pequeno e médio porte, iniciaram um processo de reestruturação de caráter defensivo baseado fundamentalmente na subcontratação e no uso do trabalho a domicílio como estratégia central de competitividade.

Novos equipamentos de base microeletrônica foram introduzidos em poucas empresas e de forma muito pontual. Nas empresas onde a reestruturação avançou mais ela se deu através da introdução de alguns elementos dos novos métodos de gestão, trabalho em grupo ou células de produção, que foram combinados com formas tayloristas de definição das tarefas e de controle da produção. Nestes casos, foram também observadas a não-utilização, ou reversão, da terceirização.

Os resultados desta pesquisa sugerem que, no setor de confecção, o porte da empresa, o tipo de mercado a que ela destina seus produtos e sua posição na cadeia de subcontratação constituem variáveis que condicionam o grau de conhecimento $e$ de adoção dos novos métodos de gestão. Em geral, as pequenas empresas confeccionistas, produzindo diferentes linhas de produtos, voltadas para nichos específicos do mercado da moda no nível regional ou nacional, demonstram pouco conhecimento das inovações organizacionais e menor disposição ou condição de adotá-las. Neste caso, não só verificamos que quanto menor o porte da empresa, maior o desconhecimento destas inovações e menor a disposição para mudança na forma tradicional de gestão da produção. Verificamos também que este desconhecimento era total quando se tratava de oficinas de costura que operavam apenas como subcontratadas.

Esta pesquisa nos permitiu identificar neste setor duas modalidades de relação de subcontratação. Na primeira, uma forma de subcontratação quase completa, para a fabricação de toda uma linha de produtos de cama e mesa, realizada através de contrato formal entre empresas de porte equivalente (uma grande e outra de tamanho médio), permitiu o estabelecimento de uma relação de parceria e a transferência de inovações gerenciais à 
empresa subcontratada. A segunda modalidade, envolvendo uma rede de pequenas empresas, pequenas ou micro oficinas de costura e trabalhadoras a domicílio, visa a redução de custos através da transferência dos gastos de produção e com a mão-deobra para as subcontratadas. Nesta rede, que se estabeleceu através da subcontratação parcial e de "contratos" informais, as relações, atravessadas por um nítido recorte de gênero, mesmo quando estabelecidas entre empresas de porte equivalente, são marcadas por uma forte assimetria. A precariedade e instabilidade do vínculo com as empresas contratantes colocam as oficinas subcontratadas - nas quais a propriedade, o gerenciamento $e$ o trabalho estão quase em $100 \%$ dos casos nas mãos de mulheres $e$ as trabalhadoras a domicílio numa posição de fragilidade $e$ as obrigam a se submeter às condições, prazos e preços impostos por aquelas. A lucratividade das contratantes depende, nesta relação, do rebaixamento dos preços e da precarização das condições de trabalho nas oficinas subcontratadas. Do mesmo modo, parte da lucratividade destas últimas depende da transferência dos riscos e de um rebaixamento ainda maior do preço pago à costureira domiciliar. Esta rede de subcontratação constitui-se, portanto, como uma rede de exploração ao transferir para seus elos inferiores instabilidade e precarização das condições de trabalho.

Elementos centrais no processo de reestruturação do setor são os baixos salários, a intensificação do ritmo de trabalho e a extensão da jornada. Potencializados pela presença maciça da mão-de-obra feminina, eles asseguram o aumento da produtividade $e$ da lucratividade em toda a rede de subcontratação. Nas empresas principais onde o processo de reestruturação mais avançou, a combinação de elementos dos novos sistemas de gestão com práticas tayloristas submete os trabalhadores a um processo de desgaste físico e emocional em decorrência da transferência de responsabilidades, da intensificação do ritmo da produção e extensão da jornada de trabalho, sem pagamento correspondente, e do medo permanente da perda do posto de trabalho. 
Redes de subcontratação

Nas empresas onde a mudança na organização da produção deu-se fundamentalmente através da redução dos postos de trabalho e da terceirização, assim como nas oficinas subcontratadas, a pressão para o cumprimento de metas de produção ou prazos de entrega tem levado igualmente à intensificação do ritmo de trabalho, às vezes, combinada com a extensão da jornada. Nas subcontratadas, estas condições estão associadas a um rebaixamento ainda maior dos salários e a uma insegurança permanente que é transferida às trabalhadoras.

Este processo de precarização atinge as trabalhadoras a domicílio de forma ainda mais aviltante. Ocupando a ponta inferior e mais frágil desta rede de subcontratação e atuando na informalidade as costureiras domiciliares são submetidas a longas jornadas de um trabalho intenso e ininterrupto. Isoladas no espaço doméstico, estas trabalhadoras recebem os preços mais baixos pagos no setor pela peça produzida e são desprovidas do amparo legal e do direito à representação sindical. A utilização do espaço privado e a articulação de habilidades socialmente construídas na esfera domiciliar com atividades produtivas tornam-se para os empregadores formas potenciais de exploração de uma força de trabalho que, embora ainda vista como qualificada, tende a se tornar facilmente substituível em um contexto de desemprego estrutural e de contínua desregulamentação do trabalho.

A intensidade do trabalho e a crescente precarização que se observa ao longo desta rede de subcontratação mostram que através dela os ganhos de produtividade se dão fundamentalmente através da extração da mais valia absoluta. Para as mulheres trabalhadoras, a centralidade da terceirização $e$ do trabalho a domicílio no processo de reestruturação do setor de confecção, além de reforçar formas pretéritas de segregação e exclusão, representa um processo de precarização gradativo que altera as suas condições de vida e torna sua força de trabalho um apêndice descartável do processo produtivo. 